NBER WORKING PAPER SERIES

TENURE CHOICE OF AMERICAN YOUTH

Donald R. Haurin

Patric H. Hendershott

Dongwook Kim

Working Paper No. 3310

NATIONAL BUREAU OF ECONOMIC RESEARCH

1050 Massachusetts Avenue

Cambridge, MA 02138

March 1990

We thank Steve Cosslett and Jan Brueckner for comments, Jackie Schriber for supplying the Coldwell-Banker data, and Shelley Beall for skillful typing. The study was supported by the Center for Real Estate Education and Research. The Ohio State University, from funds supplied by the Ohio Real Estate Education and Research Rotary Fund. This paper is part of NBER's research program in Taxation. Any opinions expressed are those of the authors and not those of the National Bureau of Economic Research. 
NBER Working Paper \#3310

March 1990

\title{
TENURE CHOICE OF AMERICAN YOUTH
}

\begin{abstract}
While there seems to be no end to estimates of housing tenure determinants, prior studies have not accounted for the simultaneity of tenure choice with household formation, labor supply or the marriage decision. Our estimates are superior to those in the literature both because we address these issues and because we better measure the cost of owning relative to renting. Accounting for simultaneity with the household formation and labor supply decisions matter. Using a household's predicted wage rate rather than its observed income doubles the response of tenure choice to the price of owning relative to renting. Including household formation selectivity correction variables cuts the response to tenure choice to the predicted wage by 25 percent. Moreover, the impact of variations in demographic variables on tenure choice is sharply reduced after correcting for selectivity bias.
\end{abstract}

Donald R. Haurin Economics Department Arps Hall Ohio State University Columbus, $\mathrm{OH} 43210$
Patric H. Hendershott Finance Department Hagerty Hall Ohio State University Columbus, $\mathrm{OH} 43210$
Dongwook Kim

Department of Public Policy and Management Ohio State University Columbus, $\mathrm{OH} 43210$ 


\section{INTRODUCTION}

While there seems to be no end to estimates of housing tenure determinants, prior studies have not accounted for the simultaneity of tenure choice with household formation, labor supply or the marriage decision. Our estimates are superior to those in the literature both because we address these issues and because we better measure the cost of owning relative to renting. The introductory comments expand on these points.

Although tenure studies of aggregate data purport to explain ownership variation in response to social, economic, and demographic variables, these studies (Rosen and Rosen, 1980; Hendershott and Shilling, 1982) actually explain the ratio of two endogenous variables: the number of owners and total households. Analogously, microeconomic studies of household tenure choice are subject to selection bias because they limit their analysis to individuals who have chosen to form a household (Rosen, 1979). ${ }^{1}$ Because similar types of variables (some unobserved) explain both choices; we suspect that bias resulting from sample selection could be substantial.

In our approach, we model the choices of whether to live with a parent or not, and, having left the parental home, whether to live with a group or not. The results of these estimations are then used to correct for potential selectivity bias in our micro based study of tenure choice. This correction is shown to be important in that one of the coefficients of the selection correction variables is statistically significant in the tenure choice equation and some coefficients in equations with and without the correction differ substantially.

The jointness of the quantities of labor supply and housing demand is shown in a study by Kohlhase (1986). One implication of this joint decision is that tenure choice studies, nearly all of which have used income as an 
explanatory variable, are subject to simultaneous equation bias because income depends on endogenous labor supply. Rather than directly treating the covariation of labor supply with household structure or mode of tenure, we use the predicted wage rate (an exogenous variable). Again, we find statistically different results when predicted wage is employed instead of predicted income.

A final source of bias in other studies of household formation is the assumption that marital status is exogenous. The usual argument is that married couples have a higher demand for privacy than singles, thus they prefer to form separate households. However, the decision to marry may be influenced by the cost of forming a household and therefore marriage and living arrangement may be determined simultaneously. We estimate a reduced form marital status equation on a set of demographic, economic, and attitudinal variables and use the predicted value derived from the probit as a measure of the respondent's demand for privacy.

Because of our emphasis on the cost of housing, we must pay particular attention to the measurement of this variable. We explicitly consider the tax treatment of households in different modes of tenure, and we append to our survey additional data that describes (by city) the relative price of constant-quality owned and rented housing. The resulting measures of the price of ownership and renting by location are more detailed and spatially comprehensive than are the price variables used in prior studies.

The remainder of this paper is divided into three sections. We first describe the unique data set employed and the measurement of our key housing price variable. We then report results, first for the decisions of whether or not to leave the parental home and, for those who have left, whether or not to "group up" or live as independent units and then the decision of whether to own or rent. A concluding section summarizes the empirical results. 


\section{DATA}

The basic data set is the National Longitudinal Survey of Youth (NLSY). Our focus in on 1987 when the respondents were aged 22 to 29 . Included in the survey is information describing a respondent's demographic characteristics (age, gender and race), labor force and income experiences, attitudes, wealth, and housing choices. From a possible sample size of 9851 , we exclude youth currently in college or living in institutions and youth residing in localities for which we have no housing cost information. We also exclude respondents living with partners because of problems in identifying home ownership and wealth.

We append to the NLSY a description of federal and state tax codes and a data set that indicates the cost of shelter in U.S. urban areas. The shelter data from Coldwell Banker report, for 175 cities, the purchase cost and rental equivalent of a "standard" 2000 square foot house with three bedrooms in neighborhoods where corporate transferees would tend to locate. ${ }^{2}$ Also included are measures of local property tax rates and the one year local house price inflation rate. Although we must omit over half of the respondents because their location is not one of those covered in the housing data, the cost of shelter index that we use is substantially more spatially comprehensive than is the American Housing Survey, the most frequently used substitute.

To test the validity of the Coldwell Banker data, we compared the derived price index to a careful study of housing prices by Moulton (1989). He forms alternative price indexes for rental costs from data that are collected to create the CPI house price series. Comparing Moulton's preferred rental index with the Coldwell Banker series in the 18 areas contained in both, we find a correlation of 0.77 . We conclude that the Coldwell Banker 
data are consistent with alternative hedonic-based price series and are superior in their spatial coverage.

The annual cost of owning relative to renting for household $j$ in city $s$ can be expressed as:

$$
\operatorname{cosT}_{s}^{j}=\frac{\left(1-\tau^{j}\right)\left(1+\theta^{j}\right)-\pi_{s}+\delta}{(R / v)_{s}}
$$

where $i$ is the pure financing rate $(0.10), \delta$ is the maintenance and depreciation rate $(0.035), \tau$ and $\theta$ are household specific tenure choice income and property tax rates, and $\pi$ and $R / V$ are the city specific expected inflation rate and rent/value ratio. The rent/value ratio and property tax rate come directly from Coldwell Banker. Expected inflation is a weighted average of the actual city house price inflation rate during the previous year (from Coldwell Banker) and the national expected inflation rate (0.04), where the local rate is given a 10 percent weight.

The tenure choice tax rate employed in the COST variable is computed using the methodology of Hendershott and slemrod (1983). For a household of income $y^{j}, r^{j}$ depends upon exemptions, deductions, and federal tax rate schedules. The number of dependents is contained in the data set, but we must estimate the amount of deductible expenses. For owners, deductions include state income taxes (derived from state tax tables), state sales taxes (estimated from 1986 federal tax table guidelines), property taxes (based on $\theta_{s}$ and $v_{s}^{j}$ ), charitable contributions (assumed to equal one percent of $y^{j}$ ), and the mortgage interest deduction (based on the amount of housing debt and a 0.10 mortgage interest rate). The amount of the standard deduction for a household is computed from federal tax regulations. To compute the tenure 
choice tax rate, we evaluate:

$$
r_{s}^{j}=\frac{\operatorname{TAXR}^{j}-\operatorname{TAXO}^{j}}{(i+\theta) V_{s}^{j}}
$$

where $\operatorname{TAXR}^{j}$ is the tax household $j$ would pay if it rented and $\operatorname{TAXO}^{j}$ if it owned. For lower income households who would have much greater standard deductions than itemized expenses if they rented, the tenure choice tax rate can be much less than their marginal tax rate. ${ }^{3}$

The variation in the locational variables in the COST expression is large: the rent-to-value ratio ranges from 0.055 to 0.13 with a mean of 0.087 , local inflation varies from negative 0.21 to positive 0.27 with a 0.057 mean, and the property tax rate is as low as 0.005 and as high as 0.052 with a mean of 0.013 . The mean value of $\cos T$ is 0.9 , and the regional variation in any of the three variables is sufficient to cause $\cos T$ to range from 0.70 to 1.10 .

In the estimation of equations explaining in-or-out of parents' house and group or separate living, we use a relative rent index computed as the ratio of the Coldwell Banker rent on a standard house in the respondent's city relative to the average rent on a standard house in all Coldwell-Banker cities. This index varies from roughly 0.5 to 2.0 .

Several additional explanatory variables were created for use in either the household formation or tenure choice equations. Real income is often used to measure the economic capacity to leave the parental home, live separately, or purchase a home. However, labor supply, and thus income, are endogenous. We employ instead a measure of predicted real wage and estimate its value for the respondent and spouse (if present) using a tobit model. 4 
Other endogenous variables that may help to explain tenure choice are wealth and whether or not the household is a married couple (see Krumm, 1989, on the endogeneity of wealth). For wealth, we use an instrument created by regressing current household wealth on a vector of variables describing a household's human capital and demographic characteristics. For the probability of the respondent being married, we use the estimated value from a probit model. 5 (Results for both of these equations are available from the authors.)

\section{EMPIRICAL RESULTS}

Our ultimate goal is to estimate the tenure choice of households in a framework that accounts for their decision to be a separate household (defined as living away from parents and not in a group). We adopt a two stage selection correction procedure similar to the model of Behrman and Wolfe (1984). In the first stage, a bivariate probit model with partial observability is estimated. The choice variables are being in-or-out of the parent's home and living with a group or separately. Selection correction variables are generated and used in a second stage analysis of tenure choice.

\section{Household Formations}

The tendency to live outside of the parent's home can be described by:

$$
I_{1 i}^{*}=X_{i} \beta_{1}+\epsilon_{1 i}
$$

and the tendency to live with a separate (non-group) household by:

$$
\mathrm{I}_{21}^{\star}-\mathrm{Z}_{\mathrm{i}} \beta_{2}+\epsilon_{21}
$$

We assume that $\epsilon_{1 i}, \epsilon_{2 i}$ are ild and are standard bivariate normal with correlation coefficient $\rho$. Neither $I_{1 i}^{*}$ nor $I_{2 i}^{*}$ is observed; rather, 


$$
\begin{aligned}
I_{1 i} & =1 \text { if } I_{1 i}^{*}>0, \\
& =0 \text { if } I_{1 i}^{*} \leq 0
\end{aligned}
$$

and

$$
\begin{aligned}
I_{21} & =1 \text { if } I_{2 i}^{*}>0, \text { it is observed if } I_{1 i}=1 \\
& =0 \text { if } I_{2 i}^{*} \leq 0, \text { it is observed if } I_{1 i}=1 \\
& - \text { unobserved if } I_{1 i}=0 .
\end{aligned}
$$

That is, we always observe whether individuals are in-or-out of their parents' home; however, if they remain with their parents, we do not observe their choice of whether to live with a group of other adults.

This model is discussed in detail by Meng and Schmidt (1985), and the $\log$ of the likelihood function is listed on their page 74 . The selection correction variables are derived in Maddala (1986, p. 368) for the bivariate probit model. In our sample, the estimated value for $\rho$ was not significantly different from zero; thus we adopt the simpler framework attained by assuming $\rho=0 .{ }^{6}$ We then enter the two selection correction variables (LAMBDA-PARENT, LAMBDA-GROUP) in the analysis of tenure choice (Maddala, P. 282).

The number of households is greater the less is "doubling up". Doubling up takes two forms: young adults remaining in (or returning to) the home of their parents, and individuals or married couples outside the parental home forming group living arrangements. Table 1 reports, by age, the proportions of youth who live out of their parents' home (rising from 628 to 898) and the proportions of individuals (rising from 448 to 738 ) and married couples (918 to 978 ) outside their parental home that live alone. 
We present the household formation estimation results of equations (3) and (4) in Tables 2 and 3 . Whether a youth resides with his or her parents depends on numerous factors. In part, normal maturation will lead to separation from parents. However, what is normal is apparently different for females and males; young males $(\leq 25.5)$ are more likely than young females to remain in the parental household, while older males are less likely. Moreover, the more children one has, the more likely one is to be out of the parental home. But the economic feasibility of living outside the parents' home is also important. The greater is one's wealth and especially the greater is one's predicted wage rate (husband and wife, if married), the more likely is one to be living outside the parental home. Conversely, the higher is the cost of independent living (rent), the less likely is one to be outside the parental home.

The most important determinants of whether or not individuals and married couples "group up" are the number of their children, their gender and race, and their predicted wealth and wage. Females and blacks are more likely to live separately, as are those with children. Moreover, the higher are predicted wealth and wages, the greater is the probability of separate living.

\section{Tenure Choice}

We limit our analysis of tenure choice to the 1565 respondents who are outside the parental home and not living with others than their spouses and children. Analysis of group tenure choice is not possible owing to lack of data on those in the group other than the respondent. Table 4 reports the ownership rate of all youth, for youth who live outside the parents' house, and for youth who do not live in groups. Among all youth, the percentage that are owners rises rapidly from 14 to 50 in just eight years. The ownership rate is obviously higher when we limit the reference group to youth who reside outside their parents' home (by about 6 percentage points) or to youth who do not live with groups (by about 10 percentage points). 
We hypothesize that the basic economic determinants of ownership are potential earnings, wealth and the cost of owning relative to renting. ${ }^{7}$ Assuming privacy to be a superior good and that owned units are more private than rentals, increases in potential earnings will raise the desire for ownership. An increased capacity to earn income may also lessen affordability constraints on ownership (Kearl, 1979). On the other hand, increases in wealth will raise ownership by reducing the risk premium required on investment in housing and lessening the impact of the downpayment constraint (Linneman and Wachter 1989, Zorn 1989). We also include the percentage of household income that is from transfer payments such as alimony, child support, and government welfare as an explanatory variable. These sources may be considered unstable by lenders, resulting in their implicit or explicit discounting of such income when considering the maximum size home loan to extend.

Noneconomic variables included in our probit equation include the demographic variables and the number of the respondent's children. of all the variables tested, only predicted wealth and a variable indicating single male headship were not statistically significant. The probit estimates are in Table 5; to provide an indication of the relative magnitudes of the response of tenure choice, Table 6 has been constructed. In this table, all variables are initially set at their sample means (listed in the appendix tables) and then varied one at a time so that we can see how the probabilities differ at ages 22 and 29, for males and females, at low and high relative owner-renter cost, etc. The estimated probabilities of ownership when all variables are assigned their sample means is 34 percent.

The age, race and female head variables work as prior research would suggest (e.g., Blackley and Follain, 1988). Holding housing costs and predicted wages and wealth constant, the probability of ownership is 25 percentage points higher for households age 29 than for those age 22, is 14 
percentage points higher for whites than blacks, and is 8 points higher for households headed by single males than single females. ${ }^{8}$

Further, the observed sample variations in the relative cost and predicted wage variables suggest substantial variation in tenure probabilities. In areas where the relative cost of ownership is high; the probability of ownership is 15 percentage points less than in low cost areas, and the probability of ownership is 24 percentage points greater for those with predicted wages twice the sample mean than for those with half the mean. Finally, if the percent of income coming from transfer payments rises to 20 percent from zero, ownership falls by 11 percentage points. This result is consistent with Haurin's 1988 finding that ownership and the percentage of income that is uncertain are negatively related.

Table 7 provides wage and cost elasticities of ownership for blacks and whites in different household structures. For married households, the wage elasticity is roughly 0.75 and the cost is -0.8 , with the black elasticities being slightly larger in absolute value. These elasticities are generally consistent with other cross-sectional work (e.g., Rosen, 1979). ${ }^{9}$ For single households, the wage elasticities are noticeably higher for females than for males and for whites than for blacks. On the other hand, the absolute values of the price elasticities are sharply higher for singles than for marrieds (2.0 to 2.8 versus 0.7 to 1.1 ).

A variety of alternative probit equations have been estimated to illustrate the importance of accounting for endogeneity and selectivity. The coefficients (and t-ratios) for the relative owner-renter cost and the income or wage variables are listed in Table 8 . The first three sets of coefficients are from equations including observed income, predicted income, and predicted wages, respectively, but not the selectivity correction variables. The last set is from an equation using predicted wage and including selectivity correction variables (repeats the estimates in Table 5). Going from left to 
right, observed income is very significant, but the relative cost variable barely works. When predicted income is used, the relative cost coefficient more than doubles, but income is no longer statistically significant.

However, the predicted wage variable is significant when it replaces predicted income, and the relative cost coefficient declines only slightly. Finally, adding the selectivity correction variables does not affect the cost coefficient, but it does reduce the wage coefficient by one fourth.

Making the selectivity adjustment has impacts beyond lowering the wage estimates. More specifically, the estimated responses to the demographic variables are sharply lower. The coefficients for children, single male head, single female head, and age, respectively, are 44, 57, 22 and 11 percent less than when the selectivity adjustment is not made.

\section{SUMMARY}

We have explained the decisions of American youth to live apart from parents, to live alone or with unrelated adults, and to purchase a house for occupation. The first two decisions need to be analyzed in order that tenure estimates free of selectivity bias can be obtained. Tenure is importantly affected by demographic variables, rising with age and being more likely for married couples, for adults with children and for white households, ceteris paribus. However, the demographic variables are significantly less important after correction for selectivity bias than before.

Economic variables also matter greatly. Homeownership is significantly greater in areas with low costs of owning relative to renting (areas having low house prices relative to rents) and is greater the larger is a household's predicted real wage. (Real rent and wage also significantly influences when youth leave their parental home.) These responses vary with race and household structure. For married households, the wage elasticity is roughly 0.75 and the cost elasticity is -0.8 with the black elasticities being slightly larger in absolute value. For single households, the wage 
elasticities are noticeably higher for females than for males and for whites than for blacks. On the other hand, the absolute values of the price elasticities are sharply higher for singles than for marrieds $(2.0$ to 2.8 versus 0.7 to 1.1 ). Using predicted wage rather than predicted or observed income affects these results importanty. With observed income, the cost responses are only about half as large; with predicted income, the income response is not statistically significant. 


\section{Footnotes}

1. An exception is Borsch-Supan (1986) who estimated a nested logit model that allowed both household structure and tenure to be choice variables.

2. The data are derived from the judgment of real estate brokers and the actual sales of comparable houses. This method is similar to that used by real estate tax appraisers. Use of the American Housing Survey would severely limit the spatial scope of our study, and the hedonic price method would have to be used to calculate costs for a standardized home.

3. All of the empirical literature cited in this paper, except Haurin, Hendershott and Ling (1988), have used marginal rather than tenure choice tax rates. For current renters, we first estimate the amount of housing that they would have consumed if they had owned and then use equations (2) and (1) to calculate $\operatorname{COST}$. The reduced from housing consumption equation is corrected for the selection bias that is introduced by only using a sample of owners (results are available from the authors). In the calculation of the amount of itemized deductions renters would have had if they had selected ownership, we assume a loan-to-value ratio of 0.90 .

4. Explanatory variables for the respondent's real wage equation include age, age squared, race, gender, education, education squared, measures of health limitations, job experience, job training, and an achievement test score. To control for spatial variation in nominal wages, we include the size of the local labor force and the population density of county of residence. The explanatory variables in the spouse wage equation are more limited because of less detail in the data set. Results for both estimations are available from the authors.

5. Explanatory variables include age, gender, race, predicted real wage, whether sexual intercourse occurred before age 16 , interactions of these variables, the desired number of children, various measures of self esteem, and the real rent of a constant-quality unit in the city in which the respondent resides. 
6. The coefficient estimates obtained by assuming $\rho=0$ are nearly identical to those estimated with the bivariate probit.

7. See Haurin, Hendershott and Ling (1988) for a formal derivation from utility maximizing behavior.

8. We have argued elsewhere that some of the age impact reflects the lesser expected mobility of older households and the lower ownership costs (smaller annual equivalent transaction cost) associated with reduced mobility (Haurin, Hendershott and Ling, 1988).

9. The price elasticities are far higher (in absolute value) than those obtained in time series studies. In earlier work we provided evidence that the high cross-section estimates are inconsistent with the observed time series behavior of homeownership rate (Haurin, Hendershott and Ling, 1988). 


\section{References}

1. Behrman, J. and B. Wolfe, "Labor Force Participation and Earnings Determinants for Women in the Special Condition of Developing Countries," Journal of Development Economics, Vo1. 15, 1984, 259-288.

2. Blackley, D. and J. Follain. "Why Do Homeownership Rates Vary Among Metropolitan Areas?," Housing Finance Review, Vo1. 7,2, 1988, $109-132$.

3. Borsch-Supan, A. "Household Formation, Housing Prices, and Public Policy Impacts," Journal of Public Economics, Vol, 30, 1986, 145-164.

4. Haurin, D. "The Effect of Income Uncertainty on Tenure Choice and Housing Demand: A Longitudinal Analysis," presented at the AREUEA national meeting, Dec. 1988 .

5. Haurin, D., P. Hendershott, and D. Ling. "Home Ownership Rates of Married Couples: An Econometric Investigation," Housing Finance Review, Vol. 7, 2, 1988, 85-108.

6. Hendershott, P. and J. Shilling, "The Economics of Tenure Choice," in C.F. Sirmans (ed.), Research in Real Estate, Vo1 1, JAI Press, 1982, 105 133.

7. Hendershott, P. and J. Slemrod. "Taxes and the User Cost of Capital for Owner Occupied Housing," AREUEA Journal, Vo1. 10, 4, 1983, 375-393.

8. Kear1, J. "Inflation, Mortgages, and Housing," Journa1 of Political Economy, Vo1. 87, 5, 1979, 1115-1138.

9. Kohlhase, J. "Labor Supply and Housing Demand for One- and Two-Earner Households," Review of Economics and Statistics, Vol. No. , 1986, 48-57. 10. Krumm, R. and A. Kelly. "Effects on Homeownership on Household Savings," Journal of Urban Economics, Vol. 21, 3, 1989, 281-244.

11. Linneman, P. and S. Wachter. "The Impacts of Borrowing Constraints on Homeownership," AREUEA Journal, Vol. 17, 4, 1989, 389-402. 
12. Maddala, G. Limited Dependent and Qualitative Variables in

Econometrics, Cambridge University Press, 1986.

13. McMahon, W.W., "Geographic Cost of Living Differences: An Update," mimeo, March 1989.

14. Meng, Chun-Lo and P. Schmidt. "On the Cost of Partial Observability in the Bivariate Probit Mode1," Internationa1 Economic Review, Vol. 26, No. 1, Feb. $1985,71-85$.

15. Moulton, B. "Interarea Indexes of the Cost of She1ter Using Hedonic Quality Adjustment Techniques," Working Paper, Division of Price and Index Number Research, U.S. Bureau of Labor Statistics, 1989.

16. Rosen, H. "Housing Decisions and the U.S. Income Tax: An Econometric Analysis," Journal of Public Economics, Vo1 11, 1979, 1-23.

17. Rosen, H. and K. Rosen, "Federal Taxes and Homeownership: Evidence from the Time Series," Journal of Political Economy, Vo1. 88, 1980, 59-75.

18. Zorn, P., "Mobility-Tenure Decisions and Financial Credit: Do Mortgage Qualification Requirements Constrain Home Ownership?" AREUEA Journal, Vol. $17,1,1989,1-16$. 
Table 1

National Percentages of Youth Residing Out of Parental Home and of Young Singles and Couples tho Live Alone

\begin{tabular}{lcrc} 
& $\begin{array}{c}\text { Out of } \\
\text { Age }\end{array}$ & \multicolumn{2}{c}{ Live Alone* } \\
\cline { 3 - 4 } 22 & Single & Married \\
23 & 62.9 & 43.8 & 90.8 \\
24 & 71.4 & 52.3 & 91.7 \\
25 & 75.0 & 57.3 & 92.7 \\
26 & 79.5 & 55.7 & 94.5 \\
27 & 82.9 & 59.7 & 95.9 \\
28 & 86.2 & 66.4 & 94.6 \\
29 & 90.0 & 75.2 & 95.3 \\
& 89.1 & 73.1 & 96.9
\end{tabular}

This table is derived from weighted 1987 NLSY data. The weights are used to correct for oversampling of minorities and youth in low income households.

*The reference group is respondents that live outside of their parents' home. 
Table 2

Probit Estimation of In or Out of Parental Household Dependent variable - RESIDE OUTSIDE OF PARENTAL HOUSEHOLD

Explanatory variable

CONSTANT
AGE
MALE
AGE*MALE
BLACK
HEALTH LIMIT
ESTEEM-B
ESTEEM - D
ESTEEM - F
CHILDREN
COLLEGE
DRUGUSE <17 (10**2)
PRED - WAGES
PRED - WAGE*MALE*SINGLE
RENT INDEX
PRED - WEALTH
PRED - MARRIED
Coefficient

$-0.94$

0.10

$-1.27$

0.05

$-0.23$

$-0.17$

0.13

$-0.17$

$-0.08$

0.29

$-0.04$

0.04

0.09

$-0.07$

$-0.53$

1.20

$-1.65$ t-ratio

Variable mean

1.4

1.00

2.8

1.5

1.4

1.2

0.6

1.3

2.0

1.0

6.5

0.5

3.4

5.6

5.0

4.1

1.4

2.2

25.33

0.46

11.78

0.26

0.01

1.43

1.52

1.59

0.73

0.45

154.96

9.30

1. 90

0.98

0.17

0.44

Log likelihood - -936 Sample size $=2355$

Percent correct prediction -80.8 
Table 3

Probit Estimation of Living Arrangement

Dependent variable = LIVE SEPARATELY

Explanatory variable Coefficient t-ratio Mean of variable

\begin{tabular}{lrrr} 
CONSTANT & 0.96 & 1.5 & 1.00 \\
AGE & -0.08 & 2.0 & 25.77 \\
MALE & -0.40 & 4.3 & 0.44 \\
BLACK & 0.83 & 3.8 & 0.25 \\
ESTEEM-B & 0.20 & 1.9 & 1.42 \\
ESTEEM-D & 0.10 & 1.1 & 1.51 \\
ESTEEM-F & -0.18 & 2.2 & 1.58 \\
CHILDREN & 0.55 & 10.3 & 0.86 \\
YEARS OUT OF PARENTS' HOUSE & 0.01 & 0.7 & 6.42 \\
PRED-WEALTH & 4.38 & 5.3 & 0.19 \\
PRED-MARRIED & 0.67 & 0.9 & 0.46 \\
RENT INDEX & 0.07 & 0.5 & 0.96 \\
PRED-WAGES & 0.03 & 1.9 & 10.17 \\
\hline
\end{tabular}

Log likelihood = -693 Sample size - 1881

Percent correct prediction -82.3 
Table 4

Ownership Rates by Age 1987

$\begin{array}{lccr}\text { Age } & \text { All youth } & \begin{array}{c}\text { Youth out-of } \\ \text { Parents' Home }\end{array} & \begin{array}{c}\text { Youth 1ivi } \\ \text { Nongroup Hous }\end{array} \\ 22 & 13.9 & 20.9 & 26.4 \\ 23 & 18.8 & 25.4 & 30.2 \\ 24 & 21.7 & 28.5 & 32.7 \\ 25 & 27.9 & 34.4 & 39.6 \\ 26 & 33.6 & 40.2 & 45.9 \\ 27 & 38.9 & 44.6 & 48.9 \\ 28 & 44.3 & 49.0 & 52.7 \\ 29 & 50.2 & 56.2 & 58.9\end{array}$

These data are weighted using the NLSY 1987 weight variable. The effect is to make the sample nationally representative. 
Table 5

Probit Estimation of Tenure Choice

Dependent variable - HOMEOWNER

Explanatory variable Coefficient t-ratio Mean of variable

\begin{tabular}{lrrr} 
CONSTANT & -2.31 & 3.2 & 1.00 \\
AGE & 0.10 & 3.8 & 25.94 \\
BLACK & -0.40 & 3.1 & 0.25 \\
FEMALE HEAD OF HOUSEHOLD & -0.47 & 2.7 & 0.23 \\
MALE HEAD OF HOUSEHOLD & -0.26 & 1.2 & 0.14 \\
8 TRANSFER INCOME & -1.36 & 3.6 & 0.10 \\
PRED-WAGES & 0.06 & 4.3 & 10.91 \\
RELATIVE OWNER-RENTER COST & -1.03 & 4.9 & 0.93 \\
PRED-WEALTH & -0.62 & 0.9 & 0.21 \\
LAMBDA-NOT IN A GROUP & 0.12 & 0.3 & 0.25 \\
LAMDA-IN/OUT OF PARENT & -1.43 & 2.2 & 0.22 \\
\hline
\end{tabular}

Log likelihood - -696 Sample size = 1529

Percent correct prediction $=77.2$ 


\section{Table 6}

The Probability of Nongroup Households Being Owners

Variable

Age

Race

Single Head

Predicted Wage

Relative Price

- Transfer Income

22
Black
Female
half mean
0.7
zero

Values

29

White

Male

twice mean

1.1

20
Probability Own

$\begin{array}{ll}22 & 47 \\ 23 & 37 \\ 12 & 20 \\ 22 & 46 \\ 42 & 27 \\ 39 & 28\end{array}$

When evaluating single heads, both the wage and value of the household-type dumy variables change. 
Table 7

Wage and Cost Elasticities

Household

Structure

\section{Married}

Single Male

Single Female

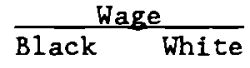

0.88

0.67

0.41

0.77

1.01

1. 36

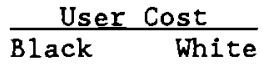

$-1.13-0.71$

$-2.79 \quad-2.46$

$-1.96 \quad-2.55$

Evaluated at the means of the other variables. 
Table 8

Alternative Probit Estimates with Endogeneity and Selectivity Corrections

$\underbrace{\text { Income or Wage }}_{\text {Regressor }}$

User Cost

Income or Wage
Observed Predicted Income

$-0.52$

(2.3)

0.25

(7.1)
Income

$-1.17$

$(5.7)$

0.18

(1.7)
Predicted

Wage

$-1.01$

$(4.9)$

0.08

$(6.0)$
Predicted Wage*

$-1.03$

(4.9)

0.06

(4.3)

t-ratios are in parentheses.

*Equation includes selectivity correction variables. 


\section{APPENDIX: VARIABLE DEFINITIONS}

All nominal values are deflated by a state specific non-housing price index. This measure was derived from an unpublished study by McMahon (1989).

AGE

HEALTH

LIMIT

ESTEEM - B

ESTEEM-D

ESTEEM-F

COLLEGE

CHILDREN

DRUGUSE

INTERCOURSE

WEALTH

CATHOLIC

JEWISH

BAPTIST

OTHER

RESIDE OUT

OF PARENT'S

HOME

WAGE

RENT INDEX

INCOME

FEMALE HEAD

MALE HEAD
As of survey date, 1987: range 22-29

Health severely limits the ability to work.

Response to the question "I feel that I have a number of good qualities", range is 1 - strongly agree to 4 strongly disagree.

Response to the question "I am able to do things as well as most other people," same range as above.

Response to the question "I take a positive attitude toward myself", same range as above.

Attended college prior to 1987.

The number of children of the respondent or the spouse that lives in the household.

A variable that indicates if the respondent used marijuana prior to age 17 .

A variable that indicates if the respondent experienced $<17$ sexual intercourse prior to age 17.

The amount of the respondent's net wealth including equity in owned housing.

A series of four variables indicating the religion the respondent was raised in. The omitted category includes the largest protestant groups (Methodists, etc.). The category OTHER includes those who identified with no religion and other small groups.

A variable that indicates the respondent does not reside with his or her parents or any other older relative such as Aunt, Uncle, Grandparent, etc.

The ratio of annual earnings to annual hours worked in 1986.

An index of rental cost in the county of residence. Derived from Coldwell Banker data and constructed as the ratio of local monthly rentals to the sample's average rental for a standard house.

Family income in calendar year 1986.

In a household with children, no adult male is present.

In a household with children, no adult female is present. 
EDUCATION

JOB

EXPERIENCE

TRAINING

POPULATION

DENSITY

LOCAL LABOR

MARKET

YEARS OUT OF PARENT'S HOME

\& TRANSFER

INCOME

ACHIEVEMENT

TEST SCORE
The highest grade completed by the respondent.

The number of years of experience with the current job.

A variable that indicates whether the respondent received job training in the last two years.

A measure of the population density of the respondent's county of residence ( 1980 census data). Used as an additional deflator variable compensating for the correlation of nominal wages with density.

A measure of the size of the local labor market as defined in the NLSY.

The number of years since the respondent first left home.

The ratio of transfer income (all public assistance and alimony or child support) to total current income.

The score from the Armed Forces Qualification Test administered to all respondents. It tests a combination of verbal and mathematical skills. 
Table 1-A

Probit Estimation of Marriage Equation

Dependent variable = MARRIED

Explanatory variable Coefficient t-ratio Variable mean

CONSTANT
AGE
MALE
AGE $\star$ MALE
BLACK
DESIRED CHILDREN
HEALTH LIMIT
INTERCOURSE $<17$
MALE INTERCOURSE $<17$
ESTEEM-B
ESTEEM-D
ESTEEM-F
PRED-WAGE
PRED-WAGE $\star M A L E$

RENT INDEX

$-1.59$

0.08

$-1.63$

0.05

$-0.68$

0.04

0.02

$-0.10$

$-0.39$

0.20

$-0.16$

$-0.07$

0.00

0.02

$-0,33$
3.5

4.5

2.6

1. 8

10.3

2. 1

0.1

1.2

3.3

3. 0

2.5

1. 3

0.2

1.0

3.7
1.00

25.53

0.46

11.78

0.26

2.46

0.01

0.39

0.24

1.43

1. 52

1. 59

6. 16

3.64

0.98

Log likelihood $=-1498$ Sample size -2355

Percent correct prediction $=64.9$ 
Table 2-A

Tobit Estimation of Respondent Wage Equation

Dependent variable $=$ HOURLY WAGE

Explanatory variable Coefficient t-ratio Variable mean

\begin{tabular}{lrrr} 
CONSTANT & 0.85 & 0.3 & 1.00 \\
AGE & -0.11 & 0.5 & 25.53 \\
AGE SQUARED $(10 * \star-2)$ & 0.20 & 0.5 & 656.83 \\
MALE & 0.42 & 11.8 & 0.46 \\
BLACK & -0.02 & 0.5 & 0.26 \\
EDUCATION & 0.08 & 1.9 & 13.04 \\
EDUCATION SQUARED (10**-2) & 0.02 & 0.1 & 175.34 \\
HEALTH LIMIT & -0.70 & 7.0 & 0.01 \\
HEALTH LIMIT-MINOR & -0.21 & 2.5 & 0.03 \\
ACHIEVEMENT TEST SCORE & 0.01 & 9.3 & 67.36 \\
JOB EXPERIENCE (10**-2) & 0.25 & 14.6 & 115.50 \\
TRAINING & 0.10 & 1.9 & 0.12 \\
POPULATION DENSITY (10**-2) & 0.03 & 0.4 & 18.18 \\
LOCAL LABOR MARKET (10**-4) & -0.05 & 0.3 & 669.20 \\
SIGMA & 0.80 & & \\
\hline
\end{tabular}

Log likelihood $=-2795$ Sample size $=2355$ 
Table 3-A

Tobit Estimates of Spouse Wage Equation

Dependent variable - HOURLY WAGE

Explanatory variable

Coefficient t-ratio

Variable mean

\begin{tabular}{lrrr} 
CONSTANT & -2.76 & 3.4 & 1.00 \\
AGE & 0.12 & 2.3 & 27.37 \\
AGE SQUARED $(10 * \star-2)$ & -0.16 & 1.8 & 766.59 \\
EDUCATION & 0.33 & 6.9 & 12.99 \\
EDUCATION SQUARED $(10 * \star-2)$ & -0.83 & 4.1 & 174.62 \\
FEMALE & -0.66 & 10.5 & 0.44 \\
POPULATION DENSITY $(10 * \star-2)$ & 0.05 & 0.4 & 15.44 \\
LOCAL LABOR MARKET $(10 * \star-4)$ & 0.25 & 0.7 & 650.86 \\
SIGMA & 0.85 & & \\
\hline
\end{tabular}

LOG LIKELIHOOD $=-1313$ SAMPLE SIZE - 1042 
Table 4-A

OLS Estimation of Wealth

Dependent Variable - CURRENT WEALTH (thousands of dollars)

Explanatory variable Coefficient t-ratio Variable mean

\begin{tabular}{lrrr} 
CONSTANT & -20.94 & 0.2 & 1.00 \\
AGE & -2.08 & 0.2 & 25.53 \\
AGE SQUARED & 0.07 & 0.4 & 656.83 \\
EDUCATION & 2.83 & 1.1 & 13.04 \\
EDUCATION SQUARED & -0.79 & 0.8 & 175.34 \\
MALE & 6.30 & 3.3 & 0.46 \\
BLACK & -4.00 & 1.5 & 0.26 \\
SPOUSE AGE & 0.27 & 0.2 & 27.36 \\
SPOUSE AGE SQUARED & 10.07 & 0.4 & 766.59 \\
SPOUSE EDUCATION & -2.13 & 0.8 & 12.99 \\
SPOUSE EDUCATION SQUARED & 0.16 & 1.5 & 174.62 \\
ACHIEVEMENT TEST SCORE & 0.17 & 2.9 & 67.36 \\
CHILDREN & -1.01 & 1.0 & 0.73 \\
CATHOLIC & 1.34 & 0.6 & 0.37 \\
JEWISH & 14.12 & 1.6 & 0.01 \\
BAPTIST & -0.96 & 0.4 & 0.24 \\
OTHER PROTESTANT & 1.42 & 0.5 & 0.15 \\
\hline
\end{tabular}

Means for spouse age and education are reported only for married respondents.

$\overline{\mathbf{R}}^{2}=0.09$ Sample size $=2355$ 
Table 5-A

OLS Estimation of the House Value that Renters Would Select Dependent variable - CURRENT HOUSE VALUE (thousands of dollars)

Explanatory variable

CONSTANT
AGE
MALE
BLACK
CHILDREN
MALE HEAD
FEMALE HEAD
\& TRANSFER INCOME
PRED - MARRIED
PRED-WEALTH $(10 \star \star-3)$
PRED - INCOME $(10 \star \star-3)$
VALUE/RENT
LAMBDA-OWNER

$\bar{R}^{2}-.34$ Sample size $=512$

Variable mean

$\begin{array}{rrr}58.82 & 1.0 & 1.00 \\ -2.10 & 1.4 & 26.68 \\ -1.71 & 0.4 & 0.42 \\ -3.61 & 0.5 & 1.12 \\ -1.00 & 0.3 & 0.12 \\ 42.06 & 3.6 & 0.05 \\ 33.87 & 2.1 & 0.04 \\ -23.51 & 0.7 & 0.02 \\ -48.55 & 2.2 & 0.54 \\ 0.43 & 1.4 & 30095.59 \\ 0.84 & 1.9 & 32512.40 \\ 6.58 & 5.4 & 11.76 \\ -30.29 & 1.3 & 0.79\end{array}$

